\title{
Correlates of local safety-related concerns in a Swedish Community: a cross-sectional study
}

\section{Agneta Kullberg*, Nadine Karlsson, Toomas Timpka and Kent Lindqvist}

Address: Linköping University, Department of Medical and Health Sciences, SE-581 83 Linköping, Sweden

Email: Agneta Kullberg* - agneta.kullberg@liu.se; Nadine Karlsson - nadine.karlsson@liu.se; Toomas Timpka - tti@ida.liu.se; Kent Lindqvist - kent.lindqvist@liu.se

* Corresponding author

Published: 8 July 2009

BMC Public Health 2009, 9:22 I doi: 10.1 |86/I47|-2458-9-22 I
Received: 5 December 2008

Accepted: 8 July 2009

This article is available from: http://www.biomedcentral.com/I47I-2458/9/22 I

(C) 2009 Kullberg et al; licensee BioMed Central Ltd.

This is an Open Access article distributed under the terms of the Creative Commons Attribution License (http://creativecommons.org/licenses/by/2.0), which permits unrestricted use, distribution, and reproduction in any medium, provided the original work is properly cited.

\begin{abstract}
Background: Crime in a neighbourhood has been recognized as a key stressor in the residential environment. Fear of crime is related to risk assessment, which depends on the concentration of objective risk in time and space, and on the presence of subjective perceived early signs of imminent hazard. The aim of the study was to examine environmental, socio-demographic, and personal correlates of safety-related concerns at the local level in urban communities. The specific aim was to investigate such correlates in contiguous neighbourhoods in a Swedish urban municipality.
\end{abstract}

Methods: A cross-sectional study design was used to investigate three neighbourhood settings with two pair-wise conterminous but socially contrasting areas within each setting. Crime data were retrieved from police records. Study data were collected through a postal questionnaire distributed to adult residents $(n=2476)$ (response rate $56 \%$ ). Composite dimensions of perceived residential safety were derived through a factor analysis. Logistic regression analysis was used to examine associations between high-level scores of the three safety-related dimensions and arealevel crime rate, being a victim of crime, area reputation, gender, age, education, country of birth, household civil status and type of housing.

Results: Three composite dimensions of perceived residential safety were identified: (I) structural indicators of social disorder; (II) contact with disorderly behavior; and (III) existential insecurity. We found that area-level crime rates and individual-level variables were associated with the dimensions structural indicators of social disorder and existential insecurity, but only individuallevel variables were associated with the dimension contact with disorderly behavior. Self-assessed less favorable area reputation was found to be strongly associated with all three factors. Being female accorded existential insecurity more than being a victim of crime.

Conclusion: We have identified environmental, socio-demographic, and personal correlates of safety-related concerns in contiguous neighbourhoods in a Swedish community. The results of this study suggest that residents' self-assessed area reputation is an important underlying mechanism of perceived safety. We also found a difference in crime rates and safety-related concerns between areas with blocks of flats compared with small-scale areas although the neighbourhoods were close geographically. 


\section{Background}

Since the mid-19th century, public health practitioners have understood that people's residential environment and housing conditions influence health outcomes $[1,2]$. Crime is among those factors suggested to be most strongly related to health in the housing environment, both by direct exposure and indirectly by residents' perception of feeling unsafe $[3,4]$. Previous research suggests that several factors influence residents' perceived safety in a neighbourhood. These factors can be divided into three main themes: crime experiences and fear of crime, demographic characteristics, and the design and quality of the residential environment [5-9].

\section{Crime experiences and fear of crime}

Crime in a neighbourhood has been recognized as a key stressor in the residential environment, when measured in absolute numbers of reported crimes in the neighbourhood and as residents' personal experience of being a crime victim. Fear of crime has also been found to have a significant negative influence on residential quality, and may have a negative impact on residents' mental health comparable to crime itself $[10,11]$.

Fear of crime is related to risk assessment, which depends on the concentration of objective risk in time and space, and on the presence of subjective perceived early signs of imminent hazard [12]. Prolonged safety-related worry and fear of crime is suggested to yield behaviour modification as it potentially decreases physical activity and limits the residents' personal freedom. A consequence of safety-related worry may therefore be 'time-space inequalities' with implications for physical and mental health $[13,14]$.

However, crime is an elusive factor with many facets. Violent crime in the immediate environment does not seem to have a great deal in common with every day offences, such as car theft or damage, in relation to perceived safety. Another aspect is the way the local newspaper communicates crime in specific neighbourhoods. Newspaper headlines about local crime may result in attitudes that divide neighbourhoods into desirable and undesirable areas.

Stories retold by neighbours who have been victims of crime themselves may result in negative attitudes, and increase the perception of isolation among residents $[15,16]$. There is thus a community-based contagious process affecting residents' perceived safety in specific areas through the influence of reports in the media and/or others around them.

\section{Demographic characteristics}

Earlier studies have reported that individual variables such as gender, age, social and economic resources influ- ence the potential risk of becoming a crime victim and fear of crime. Even though women are subject to lower crime victim rates than men, they are found to fear crime more $[17,18]$. Similarly, the elderly fear crime to a higher degree than young adults, even though they have the lowest risk of becoming a victim themselves [19]. Further, Halpern [20] found that to be unmarried or socially disconnected from conventional society in the area where you live, the more likely you are to become a victim of crime.

At neighbourhood level, the proportion of residential heterogeneity, level of education, mobility rate and density of the neighbourhood were found to be associated with perception of safety of the people living there [21,22].

\section{Design and quality of the residential environment}

Newman [23] presented the model of 'defensible space' in planning and argued for a correlation between design and function of the built environment and crime rates. He observed that in small-scale neighbourhoods in which the residents have good surveillance and control of shared outdoor space, the possibility of achieving lower factual crime rates and better maintenance is higher than in neighbourhoods without the possibility of this informal control. Newman also observed that residents who had to share a common entrance and staircase to reach their dwelling reported more perceived insecurity and a lower sense of belonging to the neighbourhood.

Land-use mix is another aspect that has been suggested to influence crime rates. For instance, non-residential property, such as shops, car-parking and public spaces, has been found to increase the number of crimes [24]. There is also evidence that visible signs such as litter and graffiti in an area communicate anti-social behaviour and how seriously the risk of becoming a crime victim has to be taken. The perception that one's neighbourhood is unsafe is likely a constant psychological irritant $[25,26]$. Several studies have suggested that perceptions of safety and fear of crime play an important role in explaining area differences in health through emotional and behavioural responses on neighbourhood quality [27-29].

Factors such as the appearance of the neighbourhood and the reputation of the area have thus been found to impact on residential well-being [30,31] but few studies have focused on how these characteristics influence safetyrelated concerns. Due to the fact that neighbourhoods are embedded in a community context in which reputations are developed, the rumours that evolve may affect residents' sense of belonging in different neighbourhoods in different ways. If a neighbourhood is held to have a specific reputation, this will influence the way its residents are perceived by others. Depending on the character of the 
reputation, this influence could have either a positive or negative effect on an individual's self-esteem [32,33].

\section{Study aims}

The aim of the study was to examine environmental, socio-demographic, and personal correlates of safetyrelated concerns at the local level in urban communities. The specific aim was to investigate such correlates in contiguous neighbourhoods in a Swedish urban municipality.

\section{Methods}

\section{Study setting}

The study was undertaken at the local level in a Swedish urban municipality (population 42,000 in 2005). Six housing areas with a total of 6300 residents (aged 20-79 years) were investigated. The selection of the housing areas was made after consultation with municipality officials in order to choose areas geographically recognized by local people. As a basis, the municipal administrative office provided a map showing the areas geographically defined for statistical purposes [34].

The six housing areas selected were geographically located two-by-two, i.e. two areas were spatially contiguous to each other in three different neighbourhood settings. The areas were given fictitious names indicating the type of property. Setting Alpha incorporates area Alpha-house (detached houses) and Alpha-flat (blocks of flats); setting Beta incorporates area Beta-mix (mixed tenure and types of houses) and Beta-flat (blocks of flats); and setting Gamma incorporates area Gamma-house (detached houses) and Gamma-flat (blocks of flats).

The proportion of non-residential land-use was higher in the three areas with blocks of flats. Within each of the three settings there was a small local community centre with both public and private services such as a grocery store, day-care centre, bus transport and a common public school, all with good access irrespective of the living area within the setting. Within each setting, the residents also shared a fair-sized green space for recreation.

The characteristics of the areas based on recorded data are presented in Table 1. The population in each of the two areas within the three settings contrasted with the other demographically and socio-economically. The residents in the small-scale areas were more socially advantaged and more residentially stable than the residents in areas with blocks of flats. Motor-vehicle density was higher in the small-scale areas (Table 1).

Registered data on crime rates for each housing area were collected from the local police office (Table 2). The data on reported crime were grouped into five categories according to the Swedish penal code: (a) crime against life and health; (b) crime against freedom and serenity; (c) theft and robbery; (d) crime of damage; (e) other crimes. Information for 3 years (2003-2005) was included to increase area stability for reported crime. In settings Alpha

Table I: Structural features of the housing areas studied ${ }^{a}$

\begin{tabular}{|c|c|c|c|c|c|c|}
\hline \multirow[b]{2}{*}{ Variable } & \multicolumn{2}{|l|}{ Setting Alpha } & \multicolumn{2}{|l|}{ Setting Beta } & \multicolumn{2}{|l|}{ Setting Gamma } \\
\hline & Alpha-house & Alpha-flat & Beta-mix & Beta-flat & Gamma-house & Gamma-flat \\
\hline Total population ${ }^{\mathrm{b}}$ & 1423 & 1918 & 1857 & 1680 & 794 & 1364 \\
\hline \multicolumn{7}{|l|}{ Residents by type of propertya } \\
\hline Blocks of flats (\%) & $10(0.7)$ & $1918(100)$ & $76 I(4 I)$ & $1675(99.7)$ & 0 & $1262(93)$ \\
\hline Detached houses (\%) & $1413(99.3)$ & 0 & $1096(59)$ & $5(0.3)$ & $794(100)$ & $97(7)$ \\
\hline Period of construction ${ }^{\mathrm{a}}$ & $1966-1975$ & $1966-1970$ & $1951-1960$ & $1966-1970$ & $197 \mid-75$ & $196 \mid-1965$ \\
\hline Resident turnover $(\%)^{\mathrm{c}}$ & $107(7.5)$ & $363(18.1)$ & $272(14.4)$ & $289(17.4)$ & $45(5.8)$ & $262(18.4)$ \\
\hline Motor-vehicle density (no.//000 inhabitants) ${ }^{d}$ & 430 & 270 & 380 & 303 & 464 & 291 \\
\hline \multicolumn{7}{|l|}{ Mean for whole municipality (index 100): } \\
\hline Gainfully employed 20-64 yearse & 114 & 81 & 102 & 80 & 104 & 85 \\
\hline Disposable income $>20$ years ${ }^{\mathrm{e}}$ & $|3|$ & 77 & 95 & 66 & 122 & 75 \\
\hline Housing allowance ${ }^{f}$ & 97 & 113 & 79 & 89 & 93 & 100 \\
\hline Social allowanceg & 48 & 109 & 84 & 124 & 27 & $|3|$ \\
\hline$>12$ years in school $(\%)^{b}$ & $264(26.1)$ & $126(9.5)$ & $28 \mid(2 I .5)$ & $142(12)$ & $98(16.9)$ & $98(9.7)$ \\
\hline High-income residents $(\%)^{\mathrm{h}}$ & $222(22)$ & $44(3.3)$ & $202(15.4)$ & $35(3)$ & $81(14)$ & $39(4)$ \\
\hline
\end{tabular}

aData source: Statistics Sweden.

bDate 30 September 2005.

'Residents' turnover I January 2005 to 3I December 2005.

dDate 3I December 2004.

eINKOPAK, 2004.

fHousing allowance for families with children (bostadsbidrag) as well as for pensioners (bostadstillägg).

gThe social allowance should give a reasonable standard of living.

hHigh income defined as $\geq 300,000$ Swedish crowns (SEK)/year in 2004. US\$I = SEK6.6; EURI = SEK9.0; date 30 December 2004. 


\begin{tabular}{|c|c|c|c|c|c|c|}
\hline & \multicolumn{2}{|c|}{ Setting Alpha } & \multicolumn{2}{|c|}{ Setting Beta } & \multicolumn{2}{|c|}{ Setting Gamma } \\
\hline & Alpha-house & Alpha-flat & Beta-mix & Beta-flat & Gamma-house & Gamma-flat \\
\hline \multicolumn{7}{|c|}{$\begin{array}{l}\text { Mean number of police reported crime//000 inhabitants per } \\
\text { year (\%) }\end{array}$} \\
\hline \multicolumn{7}{|c|}{$\begin{array}{l}\text { (a) Crime against life and health (homicide, manslaughter, } \\
\text { maltreatment) }\end{array}$} \\
\hline \multicolumn{7}{|c|}{$\begin{array}{l}\text { (b) Crime against freedom and serenity (unlawful threat, } \\
\text { molest) }\end{array}$} \\
\hline (c) Theft and robbery & $16.7(58.5)$ & $88.3(48.5)$ & 36.1 (48.7) & $49.3(48.2)$ & $20.4(60.8)$ & $81.2(48.7)$ \\
\hline (d) Crime of damage & $5.1(17.9)$ & $30.8(16.9)$ & $13.7(18.5)$ & $10.8(10.6)$ & $3.4(10.1)$ & $18.6(11.2)$ \\
\hline (e) Other crimes & $3.5(12.2)$ & $28.8(15.9)$ & $17.5(23.5)$ & $19.6(19.2)$ & 4.7 (13.9) & $36.9(22.1)$ \\
\hline Total & $28.6(100)$ & $182(100)$ & $72.9(100)$ & $102.1(100)$ & $33.6(100)$ & $165.6(100)$ \\
\hline
\end{tabular}

'Data source: Local police office. Based on the years 2003-2005.

and Gamma, the mean total crime rates in the areas with blocks of flats were five to six times those in the smallscale areas. In setting Beta only a comparatively small difference in crime rates was observed between Beta-flat and the mixed tenure area, Beta-mix. Theft and robbery were the most frequently reported crimes in all areas. The rates of reported violence and other crimes against personal safety were ten (setting Alpha) to four (setting Beta) times as high in the areas with blocks of flats than in the smallscale or mixed areas within those two settings. The residents in the small-scale areas and in the mixed area, Alpha-house, Beta-mix and Gamma-house, had organized Neighbourhood Watch programmes against crime and signposts in those areas were visible.

\section{Study population}

A cross-sectional study was conducted among the residents living in the six neighbourhoods. A sample was randomly selected from the census records by Statistics Sweden and residents aged 20-79 years were invited to participate in a survey. The questionnaire was sent by post in October 2005. The questionnaire was followed up by a reminder 4 weeks later and a further questionnaire was posted to non-respondents. A total of 1390 residents participated, accounting for $56 \%$ of the 2476 individuals who received the questionnaire.

\section{Measurements}

As there is no consensus on the term 'safety-related concerns' $[8,35]$, alternative concepts describing the term are derived from a set of relevant variables.

\section{Safety-related concerns}

The items of perceived neighbourhood disorder were adapted from the Swedish Living Conditions survey [36] (items a-f) or original for this study (g), but developed by the WHO [37]. The participants were asked to assess each question using a five-point Likert scale: to what extent they perceived (a) damage and/or graffiti, (b) littering, (c) car theft, (d) disturbance from neighbours. Participants were asked to respond using a measurement scale from 'Yes, very annoying' to 'None'. The respondents were also asked to what extent they perceived (e) tobacco smoking and ( $\mathrm{f}$ ) consumption of alcohol or use of other drugs to be an annoyance in their housing area. The respondents were also asked to estimate (g) how often their sleep was disturbed because of street noise or noisy neighbours.

Questions about general safety and fear of crime were asked to measure perceived safety based on previously used questions (with minor modifications). The item, 'Do you feel safe or insecure in your housing area in the daytime?' and the item 'Do you feel safe or insecure in your housing area during the evening and at night?' was intended to capture time and space aspects of perceived safety in the residential environment. To measure fear of crime the question, 'Do you refrain from going outdoors because of fear of crime?' was used as in previous research [11,3739].

\section{Environmental and personal correlates}

The respondents were categorized according to geographic housing area and neighbourhood setting. A question was asked on whether the residents had personal experience as a victim of crime during the last 12 months within the housing area. The reply option was 'yes' or 'no' and the item was original but modified from Statistics Sweden [36]. The participants were also asked to rate their perceived area reputation using a Likert scale: from 'very good' to 'very bad'. This question is original, but developed from studies in the west of Scotland [40]. 


\section{Area-level crime}

The area-level crime rates were represented as the mean number of police-reported crimes per 1000 inhabitants per year (year 2003-2005) according to the penal codes presented in Table 2.

\section{Demographic characteristics}

Age (in 2005) was grouped in three categories: 'young' as 20-34 years, 'middle-age' as 35-64 years and 'elderly' as 65-79 years of age. Education was grouped by length of education. The participants were classified into three groups: 'low educated' as 1-9 years in school, 'middle educated' as 10-12 years in school and 'high educated' as more than 12 years in school. Country of birth was categorized as 'born in Sweden' or 'elsewhere'. Household civil status was categorized as 'family household' when living with a spouse or significant other and/or children or 'single household' when living alone. Type of housing was categorized as 'small house' or 'flat'.

\section{Statistical method}

A factor analysis was performed to derive simplified dimensions of safety-related concerns from the set of variables measuring several aspects of perceived safety. The primary variables included in the analyses were the extent of graffiti, car theft, litter, disturbance by neighbours, disrupted sleep, disturbance by tobacco smoking and alcohol consumption, sense of safety during the day, evening and night, and fear of crime. The extraction method was principal component analysis and an orthogonal rotation was performed with varimax and Kaiser normalization using the option of replacement of missing values with the mean in SPSS [41].

For each dimension of perceived safety identified, the factor scores were computed for each respondent. Due to the skewness of the distribution of the factor scores $(p<$ $0.001)$ [42], these were dichotomised by the upper quartile, for use as input variables in subsequent statistical analyses.

A total of 1097 persons with no missing values on risk item and condition variables were included in the subsequent analyses. Logistic regressions with robust estimates of standard errors were performed to examine associations between derived concepts of safety-related concerns and area- and individual-level variables. Clustering effects within each neighbourhood were taken into account by calculating robust estimates of standard errors in Stata. The multivariate adjusted odds ratios with 95\% confidence intervals were estimated for total area crime rate (area-level characteristic), having been a victim of crime, area reputation, gender, age, education, country of birth, household civil status and type of housing (small house vs flat) (individual characteristics). A level of 5\% was considered to be statistically significant.

\section{Ethical aspects}

The study was approved by the Regional Committee for Research Ethics at Linköping University.

\section{Results}

\section{Non-responder characteristics}

The response rate varied between areas and was the highest in area Gamma-house (detached houses), 158/231 (68\%), and lowest in area Gamma-flat (blocks of flats), $175 / 391$ (45\%). External dropout analysis showed no statistically significant differences in gender among the responders compared to the study population in five of the six areas, but in area Alpha-house more females and fewer males responded than expected. The responders were older than the study population in three areas (Alpha-house, Beta-mix, Beta-flat). The group of 'middle educated' (10-12 years) responders was underrepresented in three areas (Alpha-house, Alpha-flat, Beta-mix) but there was no statistically significant difference in the distribution of country of birth between the responders and the study population (Table 3 ).

\section{Composite dimensions of deficient residential safety}

Three composite dimensions of residential safety-related concerns were identified in the factor analysis: 'structural indicators of social disorder', 'contact with disorderly behaviour' and 'existential insecurity' (Table 4). Each composite dimension was associated with different sets of modifying items and conditions.

\section{Structural indicators of social disorder}

Area-level crime rates were associated with reporting by the residents of structural indicators of social disorder (OR 1.010, CI 1.007-1.013) (Table 5). Residents who estimated their area reputation as less good were more than twice as likely to report concerns about structural indicators of social disorder (OR 2.86, CI 2.13-3.84). For females, the odds ratio of reporting such concerns was lower (OR 0.78, CI 0.65-0.94). Residents born abroad reported concerns about structural indicators of social disorder to a lower extent (OR 0.68, CI 0.55-0.84) than residents born in Sweden. Living in a flat was associated with concerns in this dimension (OR 1.37, CI 1.01-1.84), but having been a victim of crime, age, and household civil status were not associated (Table 5).

\section{Contact with disorderly behaviour}

The odds ratio for reporting contact with disorderly behaviour was more than five times higher for residents living in flats than for those living in detached houses (OR 5.58, CI 3.06-10.17) (Table 5). Personal experience of crime during the last 12 months increased the likelihood of being concerned about disorderly behaviour in the residential area to 1.61 (CI 1.03-2.51). Such concerns were also associated with living in a neighbourhood with estimated less favourable reputation (OR 2.91, CI, 2.12- 
Table 3: Demographic characteristics of the survey respondents and study population in the housing areas studied

\begin{tabular}{|c|c|c|c|c|c|c|}
\hline & \multicolumn{2}{|l|}{ Setting Alpha } & \multicolumn{2}{|l|}{ Setting Beta } & \multicolumn{2}{|l|}{ Setting Gamma } \\
\hline & $\begin{array}{l}\text { Alpha-house } \\
\mathrm{n}(\%)\end{array}$ & $\begin{array}{l}\text { Alpha-flat } \\
\text { n (\%) }\end{array}$ & $\begin{array}{l}\text { Beta-mix } \\
\text { n (\%) }\end{array}$ & $\begin{array}{l}\text { Beta-flat } \\
n(\%)\end{array}$ & $\begin{array}{l}\text { Gamma-house } \\
\mathrm{n}(\%)\end{array}$ & $\begin{array}{l}\text { Gamma-flat } \\
n(\%)\end{array}$ \\
\hline \multicolumn{7}{|l|}{ Gender distribution } \\
\hline \multicolumn{7}{|l|}{ Respondents } \\
\hline Male & $108(40.1)$ & $101(42.1)$ & $139(44.4)$ & $108(46)$ & $68(43.0)$ & $77(44.0)$ \\
\hline Female & $14 \mid(52.4)$ & $125(52.1)$ & $163(52.1)$ & III (47.2) & $85(53.8)$ & $82(46.9)$ \\
\hline Partial drop-outs: non- respondent gender & $20(7.4)$ & $14(5.8)$ & II (3.5) & $16(6.8)$ & $5(3.2)$ & $16(9.1)$ \\
\hline Total & 269 & 240 & 313 & 235 & 158 & 175 \\
\hline \multicolumn{7}{|l|}{ Study population } \\
\hline Male & $514(50.8)$ & $646(48.9)$ & $632(48.3)$ & $569(48.2)$ & $280(48.2)$ & $507(51.6)$ \\
\hline Female & $497(49.2)$ & $676(5 \mathrm{I} .1)$ & $677(51.7)$ & $611(51.8)$ & $30 I(5 I .8)$ & $476(48.4)$ \\
\hline Total & 1011 & 1322 & 1309 & 1180 & 581 & 983 \\
\hline$p$-value & $0.035^{*}$ & 0.246 & 0.480 & 0.766 & 0.409 & 0.461 \\
\hline \multicolumn{7}{|l|}{ Age distribution } \\
\hline \multicolumn{7}{|l|}{ Respondents } \\
\hline 20-34 years & $21(7.8)$ & $56(23.3)$ & $51(16.3)$ & $59(25.1)$ & $25(15.8)$ & $35(20)$ \\
\hline $35-64$ years & $170(63.2)$ & $132(55)$ & $173(55.3)$ & $98(41.7)$ & $87(55.1)$ & $95(54.3)$ \\
\hline $65-79$ years & $74(27.5)$ & $50(20.8)$ & $84(26.8)$ & $74(31.5)$ & $45(28.5)$ & $40(22.9)$ \\
\hline Partial drop-outs: non-respondent age & $4(1.5)$ & $2(0.8)$ & $5(1.6)$ & $4(1.7)$ & $I(0.6)$ & $5(2.9)$ \\
\hline Total & 269 & 240 & 313 & 235 & 158 & 175 \\
\hline \multicolumn{7}{|l|}{ Study population } \\
\hline 20-34 years & $13 \mid(\mid 3)$ & $406(30.7)$ & $321(24.5)$ & $362(30.7)$ & $97(16.7)$ & $280(28.5)$ \\
\hline $35-64$ years & $654(64.7)$ & $695(52.6)$ & $712(54.4)$ & $529(44.8)$ & $328(56.5)$ & $515(52.4)$ \\
\hline $65-79$ years & $226(22.4)$ & $221(16.7)$ & $276(21.1)$ & $289(24.5)$ & $156(26.9)$ & $188(19.1)$ \\
\hline Total & 1011 & 1322 & 1309 & 1180 & 581 & 983 \\
\hline$p$-value & $0.027^{*}$ & 0.051 & $0.004^{* *}$ & $0.044^{*}$ & 0.897 & 0.08 \\
\hline \multicolumn{7}{|l|}{ Country of birth } \\
\hline \multicolumn{7}{|l|}{ Respondents } \\
\hline Born in Sweden & $253(94.1)$ & $165(68.8)$ & $283(90.4)$ & $186(79.1)$ & $136(86.1)$ & $115(65.7)$ \\
\hline Born elsewhere & $15(5.6)$ & $75(3 \mid .3)$ & $30(9.6)$ & $48(20.4)$ & $20(12.7)$ & $56(32)$ \\
\hline Partial drop-outs: non-respondent country of birth & $\mathrm{I}(0.4)$ & 0 & 0 & $\mathrm{I}(0.4)$ & $2(1.3)$ & $4(2.3)$ \\
\hline Total & 269 & 240 & 313 & 235 & 158 & 175 \\
\hline \multicolumn{7}{|l|}{ Study population } \\
\hline Born in Sweden & $939(92.9)$ & $870(65.8)$ & II $88(90.8)$ & $891(75.5)$ & $503(86.6)$ & $612(62.3)$ \\
\hline Born elsewhere & $72(7.1)$ & $452(34.2)$ & $121(9.2)$ & $289(24.5)$ & $78(13.4)$ & $371(37.7)$ \\
\hline Total & 1011 & 1322 & 1309 & 1180 & 581 & 983 \\
\hline$p$-value & 0.378 & 0.375 & 0.852 & 0.192 & 0.843 & 0.212 \\
\hline \multicolumn{7}{|l|}{ Years in school } \\
\hline \multicolumn{7}{|l|}{ Respondents } \\
\hline 1-9 years & $82(30.5)$ & $98(40.8)$ & $88(28.1)$ & $94(40)$ & $55(34.89)$ & $71(40.6)$ \\
\hline $10-12$ years & $78(29)$ & $74(30.8)$ & $106(33.9)$ & $76(32.3)$ & $62(39.2)$ & $63(36)$ \\
\hline$\geq 12$ years & $71(26.4)$ & $26(10.8)$ & $82(26.2)$ & $31(13.2)$ & $26(16.5)$ & $19(10.9)$ \\
\hline Partial drop-outs: non-respondent years in school & $38(14.1)$ & $42(17.5)$ & $37(11.8)$ & $34(14.5)$ & $15(9.5)$ & $22(12.6)$ \\
\hline Total & 269 & 240 & 313 & 235 & 158 & 175 \\
\hline \multicolumn{7}{|l|}{ Study population } \\
\hline $1-9$ years & $266(26.3)$ & $564(42.7)$ & $365(27.9)$ & $505(42.8)$ & $|7|(29.4)$ & $438(44.6)$ \\
\hline $10-12$ years & $481(47.6)$ & $632(47.8)$ & $663(50.6)$ & $533(45.2)$ & $312(53.7)$ & $447(45.5)$ \\
\hline$\geq 12$ years & $264(26.1)$ & $126(9.5)$ & $281(21.5)$ & $142(12)$ & $98(16.9)$ & $98(10)$ \\
\hline Total & 1011 & 1322 & 1309 & 1180 & 581 & 983 \\
\hline$p$-value & $0.001 * *$ & $0.017^{*}$ & $0.00 I^{* *}$ & 0.116 & 0.064 & 0.493 \\
\hline No. of questionnaires delivered $(N=2510)$ & 413 & 518 & 514 & 443 & 231 & 391 \\
\hline \multicolumn{7}{|l|}{ Drop-out on account of deceased or moved $(N=34)$} \\
\hline Respondent rate $(N=1390,56.1 \%)$ & $269(65.1)$ & $240(46.3)$ & $313(60.9)$ & $235(53)$ & $158(68.4)$ & I 75 (44.8) \\
\hline
\end{tabular}

$* \chi^{2}$ test significant at $p<0.05$. ** $\chi^{2}$ test significant at $p<0.0$ I. 
Table 4: Factor loadings for three dimensions of perceived safety $(n=1390)$

\begin{tabular}{llll}
\hline & \multicolumn{2}{l}{ Derived factor } & \\
\cline { 2 - 4 } & I. Structural indicators of social disorder & II. Contact with disorderly behaviour & III. Existential insecurity \\
\hline Percentage of variation explained & 40.2 & 12.1 & 10.3 \\
Cronbach alpha & 0.78 & 0.78 & 0.65 \\
Factor loadings & & & \\
Graffiti & 0.83 & & 0.83 \\
Car theft & 0.74 & 0.82 & 0.58 \\
Litter & 0.73 & 0.54 & 0.74 \\
Disturbing neighbours & & & 0.73 \\
Disturbed night rest & & & 0.73 \\
Tobacco smoking & & & \\
Alcohol consumption & & & \\
Sense of safety in evening and night & & & \\
Fear of crime & & & \\
Sense of safety in daytime & & & \\
\hline
\end{tabular}

aFactor loadings $<0.5$ are not represented.

4.00). The odds ratio for reporting contact with disorderly behaviour was significantly lower for the elderly (65-79 years) (OR 0.51, CI 0.38-0.70). There were no associations between area-level crime, gender, education, country of birth and contact with disorderly behaviour, but for single households the odds ratio was 1.57 times higher (CI 1.28-1.94) than for family households.

\section{Existential insecurity}

The odds ratio of reported existential insecurity (feeling insecure in the residential area during the day or in the evening or at night, and fear of crime) in the neighbourhood was associated with area-level crime (OR 1.003, CI 1.001-1.006) but not significantly associated with being a crime victim during the last 12 months (OR 1.42, CI 0.85-2.37). Residents who thought their area reputation was less good had more than twice the odds ratio (OR 2.67, CI 1.64-4.35) for experiencing existential insecurity in the neighbourhood. Existential insecurity in the neighbourhood was reported four times more often by female residents (OR 4.54, CI 3.21-6.43) compared with males, and being elderly (65-79 years) increased the odds ratio for perceived existential insecurity to 1.72 (CI 1.20-2.46) times that of younger residents. Education, country of birth, household civil status, and type of housing were not associated with existential insecurity in the neighbourhood (Table 5).

\section{Discussion}

In our study design, an attempt was made to cover several complementary dimensions of perceived safety in the residential environment. The three derived dimensions captured almost two-thirds of the total item variance. As could be expected, the dimension 'structural indicators of social disorder' was associated with the area-level of crime and to living in a flat. Previous research [24] suggested that a land-use structure with large non-residential space, such as in the present areas with blocks of flats, increases crime rates. A corresponding association between factual crime rates and perceived structural indicators of social disorder could be observed in the areas with detached houses and little non-residential space, where the residents assessed the occurrence of threatening physical signs as less serious; the crime rates were also relatively low. It is possible that signs of disorder in the residential environment give rise to safety-related concerns among residents, especially in combination with local reports of violence, assaults or rape communicated through neighbours or the media. In areas where reports of crime and signs of disorder co-exist, a process of stigmatization could develop giving an area the reputation of being a dangerous place $[43,44]$. In the classic theory of 'broken windows', Wilson and Kelling [45] suggest that signs of neighbourhood disorder are perceived as a warning sign of low reciprocity. More recent research has indicated that physical signs of social disorder indicate neighbourhood deterioration, trigger general insecurity among residents and stimulate outward migration [46-49].

We observed a similar pattern of clear differentiation between residents in different types of housing for the dimension 'contact with disorderly behaviour'. Residents living in flats reported more severe problems with disturbance from neighbours, alcohol consumption, and smoking, and their sleep was disturbed more frequently because of noise in the residential environment. Contact with this sort of disorderly behaviour could be interpreted as a lack of the normal inhibitors of incivilities and crime, which produces insecurity. If such a pattern lasts for a prolonged in time, residents may suffer from the consequences of safety-related concerns in the living environment as a source of accumulated stress with nega- 
Table 5: Logistic regression analysis with robust estimates of standard errors for three dimensions of perceived safety

\begin{tabular}{|c|c|c|c|c|c|c|c|c|c|c|}
\hline \multirow[t]{2}{*}{ Variables } & \multirow[b]{2}{*}{$N(\%)$} & \multicolumn{3}{|c|}{ Structural indicators of social disorder } & \multicolumn{3}{|c|}{ Contact with disorderly behaviour } & \multicolumn{3}{|c|}{ Existential insecurity } \\
\hline & & $\begin{array}{l}\text { Exposed } \\
\text { cases, } \\
n(\%)\end{array}$ & $\begin{array}{l}\text { Adjusted } \\
\mathrm{OR}^{\mathrm{a}}\end{array}$ & $95 \% \mathrm{Cl}$ & $\begin{array}{l}\text { Exposed } \\
\text { cases, } \\
n(\%)\end{array}$ & $\begin{array}{l}\text { Adjusted } \\
\mathrm{OR}^{\mathrm{a}}\end{array}$ & $95 \% \mathrm{Cl}$ & $\begin{array}{l}\text { Exposed } \\
\text { cases, } \\
n(\%)\end{array}$ & $\begin{array}{l}\text { Adjusted } \\
\mathrm{OR}^{\mathrm{a}}\end{array}$ & $95 \% \mathrm{Cl}$ \\
\hline \multicolumn{11}{|c|}{ Area-level characteristics } \\
\hline $\begin{array}{l}\text { Total area } \\
\text { crime }^{\text {b }}\end{array}$ & - & - & $1.01 * * *$ & $1.01-1.01$ & - & 1.00 & $0.99-1.00$ & - & $1.00 * *$ & $1.00-1.01$ \\
\hline \multicolumn{11}{|c|}{ Individual characteristics } \\
\hline \multicolumn{11}{|c|}{ Experience of crime } \\
\hline No $(0)$ & $982(89.5)$ & $225(22.9)$ & I & & $222(22.6)$ & I & & $\begin{array}{l}218 \\
(22.2)\end{array}$ & 1 & \\
\hline Yes (I) & $115(10.5)$ & $\begin{array}{l}51 \\
(44.3)\end{array}$ & 1.61 & $0.82-3.18$ & $\begin{array}{l}49 \\
(42.6)\end{array}$ & $1.61^{*}$ & $|.03-2.5|$ & $\begin{array}{l}35 \\
(30.4)\end{array}$ & 1.42 & $0.85-2.37$ \\
\hline \multicolumn{11}{|l|}{ Area reputation } \\
\hline Good (0) & $416(37.9)$ & $\begin{array}{l}41 \\
(9.9)\end{array}$ & 1 & & $\begin{array}{l}39 \\
(9.4)\end{array}$ & 1 & & $\begin{array}{l}53 \\
(12.7)\end{array}$ & I & \\
\hline $\begin{array}{l}\text { Not very } \\
\text { good (I) }\end{array}$ & $681(62.1)$ & $235(34.5)$ & $2.86 * * *$ & $2.13-3.84$ & $232(34.1)$ & $2.91 * * * *$ & $2.12-4.00$ & $\begin{array}{l}200 \\
(29.4)\end{array}$ & $2.67^{* * * *}$ & $1.64-4.35$ \\
\hline \multicolumn{11}{|l|}{ Gender } \\
\hline Male & $507(46.2)$ & $139(27.4)$ & 1 & & $|3|(25.8)$ & I & & $\begin{array}{l}54 \\
(10.7)\end{array}$ & 1 & \\
\hline Female & $590(53.8)$ & $137(23.2)$ & $0.78 * *$ & $0.65-0.94$ & 140 (23.7) & 0.93 & $0.79-1.10$ & $\begin{array}{l}199 \\
(33.7)\end{array}$ & $4.54 * * *$ & $3.21-6.43$ \\
\hline \multicolumn{11}{|l|}{ Age (years) } \\
\hline $20-34$ & $214(19.5)$ & $\begin{array}{l}64 \\
(29.9)\end{array}$ & 1 & & $\begin{array}{l}76 \\
(35.5)\end{array}$ & 1 & & $\begin{array}{l}55 \\
(25.7)\end{array}$ & 1 & \\
\hline $35-64$ & $619(56.4)$ & $166(26.8)$ & 1.36 & $0.96-1.92$ & $153(24.7)$ & 1.00 & $0.77-1.32$ & $\begin{array}{l}117 \\
(18.9)\end{array}$ & 0.80 & $0.58-1.09$ \\
\hline $65-79$ & $264(24.1)$ & $\begin{array}{l}46 \\
(17.4)\end{array}$ & 0.87 & $0.5 \mathrm{I}-\mathrm{I} .47$ & $\begin{array}{l}42 \\
(15.9)\end{array}$ & 0.51 **** & $0.38-0.70$ & $\begin{array}{l}81 \\
(30.7)\end{array}$ & $1.72 * *$ & $1.20-2.46$ \\
\hline \multicolumn{11}{|l|}{ Education } \\
\hline $1-9$ years & 427 (38.9) & $\begin{array}{l}97 \\
(22.7)\end{array}$ & 1 & & $\begin{array}{l}94 \\
(22.0)\end{array}$ & 1 & & $\begin{array}{l}115 \\
(26.9)\end{array}$ & 1 & \\
\hline $10-12$ years & $433(39.5)$ & $|3|(30.3)$ & $1.40 *$ & $1.01-1.94$ & $129(29.8)$ & 1.27 & $0.79-2.05$ & $\begin{array}{l}95 \\
(21.9)\end{array}$ & 0.95 & $0.68-1.31$ \\
\hline$\geq 12$ years & $237(21.6)$ & $\begin{array}{l}48 \\
(20.3)\end{array}$ & 1.20 & $0.83-1.74$ & $\begin{array}{l}48 \\
(20.3)\end{array}$ & 1.27 & $0.69-2.34$ & $\begin{array}{l}43 \\
(18.1)\end{array}$ & 0.82 & $0.53-1.27$ \\
\hline \multicolumn{11}{|l|}{ Country of birth } \\
\hline $\begin{array}{l}\text { Born in } \\
\text { Sweden }\end{array}$ & 909 (82.9) & $218(24.0)$ & I & & $209(23.0)$ & I & & $\begin{array}{l}204 \\
(22.4)\end{array}$ & I & \\
\hline $\begin{array}{l}\text { Born } \\
\text { elsewhere }\end{array}$ & $188(17.1)$ & $\begin{array}{l}58 \\
(30.9)\end{array}$ & $0.68 * * *$ & $0.55-0.84$ & $\begin{array}{l}62 \\
(33.0)\end{array}$ & 1.04 & $0.74-1.47$ & $\begin{array}{l}49 \\
(26.1)\end{array}$ & 1.02 & $0.69-|.5|$ \\
\hline \multicolumn{11}{|c|}{ Household civil status } \\
\hline $\begin{array}{l}\text { Family } \\
\text { household }\end{array}$ & 831 (75.8) & 197 (23.7) & I & & $168(20.2)$ & I & & $\begin{array}{l}184 \\
(22.1)\end{array}$ & 1 & \\
\hline $\begin{array}{l}\text { Single } \\
\text { household }\end{array}$ & $266(24.2)$ & $\begin{array}{l}79 \\
(29.7)\end{array}$ & 0.85 & $0.61-1.20$ & $103(38.7)$ & $1.57^{* * * *}$ & $1.28-1.94$ & $\begin{array}{l}69 \\
(25.9)\end{array}$ & 0.94 & $0.61-1.47$ \\
\hline \multicolumn{11}{|l|}{ Type of housing } \\
\hline Small house & $453(4 \mid .3)$ & $\begin{array}{l}52 \\
(11.5)\end{array}$ & 1 & & $\begin{array}{l}35 \\
(7.7)\end{array}$ & 1 & & $\begin{array}{l}79 \\
(17.4)\end{array}$ & I & \\
\hline Flat & 644 (58.7) & $224(34.8)$ & $1.37 *$ & $1.01-1.84$ & $236(36.6)$ & $5.58 * * *$ & $3.06-10.17$ & $\begin{array}{l}174 \\
(27.0)\end{array}$ & 0.85 & $0.59-1.23$ \\
\hline
\end{tabular}

OR, odds ratio; $\mathrm{Cl}$, confidence interval. $*_{p}<0.05 ; * * p<0.01$; $* * * p<0.00 \mathrm{I}$.

aORs are adjusted for all other variables in the table.

bTotal mean number of police-reported crimes/1000 inhabitants per year. 
tive impact on well-being and indirectly on health [50]. The two composite dimension; 'structural indicators of social disorder' and 'contact with disorderly behaviour' both reflect the construct collective efficacy introduced by Sampson [51], and defined as the linkage of social control and cohesion that reproduces the norms for behaviour in neighbourhood environments. Several studies demonstrate that where the rules of behaviour are unclear, residents will experience mistrust and safety-related concerns. Poor social and economic resources and residential instability in a neighbourhood have been found to be strongly associated with violence mediated by low collective efficacy [52-54]. This pattern could be applicable to the present study; in the areas with comparatively high violence-related crime rates (blocks of flats), the levels of education and income were lower, and the density of the residents and the mobility rate were higher than for areas with low violence rates (small-scale housing areas). The occurrence of violence in the immediate environment may generate a situation where it is harder for residents to build trustworthy bonds with their neighbours [54]. If social disturbances are reported and communicated regularly from particular areas in the local media, this negative information will accumulate over time and have a negative impact on the image of a specific area and partly mould its identity among its residents.

In accordance with previous studies, we found that female gender was strongly associated with the composite dimension 'existential insecurity' (to feel unsafe during the day or in the evening or at night and fear of crime). It is possible that this dimension reflects an individual vulnerability, in contrast to the other concepts, which is derived from determinants in physical space and the built environment to a higher extent [55]. It is also known that persons who are the object of violence or threats are often closely related to the criminal [18]. Arguments have been made on the need for local safety promotion programs to take different perceptions of males and females into account [35]. To spend time outdoors in the evening and at night has been found to be correlated with an increased risk of being robbed or mugged [56]. Theft and robbery were the most prevalent types of crime in all areas in our study. Thus, area-level crime was associated with the existential insecurity dimension of safety-related concerns, but having been a victim of crime and type of housing were not. These findings could be interpreted to mean that existential insecurity is a more complex issue than area of residence, type of housing and victimization. On the other hand, in this context it is also interesting to observe that country of birth, level of education and living alone were not important for perceived 'existential insecurity'.

We found that area-level crime rate and individual-level variables were associated with the composite dimensions 'structural indicators of social disorder' and 'existential insecurity', but only individual-level variables were associated with the dimension 'contact with disorderly behaviour'.

We investigated whether there was an association between the residents' self-estimated area reputation and safetyrelated concerns. Our data show that all three derived safety-related dimensions of safety-related concerns ('structural indicators of social order', 'contact with disorderly behaviour' and 'existential insecurity ') were strongly influenced by whether the residents perceived themselves to live in a residential environment with a less favourable reputation. This study indicates that self-assessed area reputation is an invisible factor that strongly influences the sense of insecurity among residents. Why area reputation is a mechanism that has strong consequences for perceived safety among residents is not investigated here but it is possible that reputation is related to social dimensions in the residents' immediate environment. In this regard, clues can be found in studies suggesting that the occurrence of crime and incivilities is associated with the development of perceptions that one's neighbourhood is a 'bad place' $[57,58]$. Another plausible clue is that if the estimated reputation is an essential part of the lives of residents, mental images of the area could either strengthen the attachment to the neighbourhood if you live in a 'good place' or weaken the attachment if you live in a 'bad place'. The mental images the residents have of their neighbourhood are likely to have serious consequences on the community spirit of their neighbourhood, leading to either a positive or negative situation in which residents increase or reduce their willingness to come together. A less favourable reputation develops a process of stigmatization as a 'bad area', leading to an ongoing migration process in which residents who are able, move away from the area. Consequently the people with lesser ability and resources remain. In contrast, the reputation of a desirable 'good area' is attractive and implies a safe and secure place in which to live.

Living alone was found to be positively associated with 'contact with disorderly behaviour' when compared with residents living in families. This may be in line with earlier studies that suggested that living alone could lead to social isolation and thereby a more vulnerable situation [20], which likely also generates anxiety.

The three small-scale areas in this study had implemented Neighbourhood Watch programs. The lowest crime rates were recorded from these areas and the residents in detached houses reported the highest perceived safety. The rationale behind Neighbourhood Watch programs is to contribute to lower crime rates and to a perception of safety in a neighbourhood through increased reciprocity, e.g. looking after strangers and property and improved 
informal social control. However, a pre-existing high social capital in the neighbourhood seems to be a prerequisite for implementation of a successful Neighbourhood Watch program $[18,20,59]$. In Sweden, the majority of Neighbourhood Watch programs are implemented in wealthy small-scale areas [60]. Therefore, if Neighbourhood Watch programs are to become an effective method of building safer neighbourhoods, our results suggest that the design of these programs need to be adjusted to make them suitable for introduction in areas with blocks of flats.

\section{Study limitations}

There are important limitations that have to be considered when trying to draw conclusions from this study. A methodological limitation is the cross-sectional design, which does not allow causal inferences. Given this study design, and the fact that the variables in the field of study are strongly interrelated, it is not possible to determine if a negative area reputation is a cause or a consequence of low perceived safety. Area reputation appears to be part of a complex pathway through which the effects of crime on perceived safety are mediated. However, our results are only indicative on this matter.

A number of variables that could contribute to perceived safety were not included in this study, e.g. health indicators, individual and contextual social capital, length of residence, and objective neighbourhood characteristics (concentrated affluence, unemployment rate, outdoor conditions such as lighting in public areas, etc.) $[33,61,62]$.

In previous housing area studies based on postal questionnaires in Scotland [63] and Australia [64], the participation rates were around $50 \%$, similar to the $56 \%$ achieved in this study. The pattern of non-response was slightly skewed in the present study according to gender, age and education for some areas. Some findings may therefore have been somewhat overestimated, due to the fact that the participants included a higher proportion of women (Alpha-house) and older persons (Alpha- house, Beta-mix, Beta-flat) compared with the total area population.

\section{Conclusion}

We have identified environmental, socio-demographic, and personal correlates of safety-related concerns in contiguous neighbourhoods in a Swedish community. The results indicate that self-assessed area reputation was important for all dimensions of safety-related concerns among the residents. We also found a difference in crime rates and safety-related concerns between areas with blocks of flats compared with small-scale areas, although these neighbourhoods were close geographically with a shared local centre.
Our findings suggest that the implementation of modern Swedish housing policy targeting social integration has resulted in inequalities in safety-related concerns among residents. Future research on whether Neighbourhood Watch programs are an effective way to promote safer neighbourhoods is warranted, as well as the development of methods to implement these programs in areas with blocks of flats.

\section{Competing interests}

The authors declare that they have no competing interests.

\section{Authors' contributions}

$\mathrm{AK}, \mathrm{KL}$, TT planned the study. AK was the main author of this paper and was involved in all steps to create the manuscript. NK designed the statistical analysis. All authors read drafts of the manuscript, made comments and suggestions to improve the text before they agreed to submit it for publication.

\section{Acknowledgements}

This study was funded by the Swedish National Rescue Service Agency and The Building Foundation Platen.

\section{References}

I. Nightingale F: Florence Nightingale on Society and Politics, Philosophy, Science, Education and Literature [1820-19|10]. In Electronic reproduction Volume 5. Edited by: McDonald L. Palo Alto, CA; 2003.

2. Rosen G: A History of Public Health [first published 1958]. New York: John Hopkins; 1993.

3. Shaw C, McKay H: Juvenile Delinquency and Urban Areas Chicago: University of Chicago Press; 1942.

4. Kawachi I, Kennedy BP, Wilkinson RG: Crime: social disorganization and relative deprivation. Soc Sci Med I999, 48(6):719-731.

5. Fuller-Thomson E, Hulchanski JD, Hwang S: The housing/health relationship: what do we know? Rev Environ Health 2000, I 5(I2): 109-133.

6. Jackson RJ: The impact of the built environment on health: an emerging field. Am J Public Health 2003, 93(9): I382-1384.

7. van Kamp I, van Loon J, Droomers M, de Hollander A: Residential environment and health: a review of methodological and conceptual issues. Rev Environ Health 2004, I9(3-4):381-40I.

8. Bonnefoy $X$ : Inadequate housing and health: an overview. Int J Environ Pollut 2007, 30(3-4):4II-429.

9. Austin DM, Furr LA, Spine M: The effects of neighborhood conditions on perceptions of safety. J Crim Just 2002, 30(5):4I 7-427.

10. Baumer TL: Testing a general model of fear of crime: data from a national sample. J Res Crime Delinq 1985, 22(3):239-255.

II. Green G, Gilbertson JM, Grimsley MF: Fear of crime and health in residential tower blocks. A case study in Liverpool, UK. Eur J Public Health 2002, I 2(I): I0-15.

12. Skogan WG, Maxfield MG: Coping with Crime. Individual and Neighborhood Reactions London: Sage Publications; 198I.

13. Whitley R, Prince M: Fear of crime, mobility and mental health in inner-city London, UK. Soc Sci Med 2005, 61 (8):1678-1688.

14. Bennett GG, McNeill LH, Wolin KY, Duncan DT, Puleo E, Emmons KM: Safe to walk? Neighborhood safety and physical activity among public housing residents. PLOS Med 2007, 4(10): 1599-1606. discussion 1607

15. Heath L: Impact of newspaper crime reports on fear of crime: multimethodological investigation. J Pers Soc Psychol 1984, 47(2):263-276.

16. Baum F, Palmer C: 'Opportunity structures': urban landscape, social capital and health promotion in Australia. Health Promot Int 2002, I7(4):35|-36I.

17. Evans DJ, Fletcher M: Fear of crime: testing alternative hypotheses. Appl Geog 2000, 20:395-4II. 
18. Pain R: Place, social relations and the fear of crime: a review. Prog Hum Geog 2000, 24(3):365-387.

19. Acierno R, Rheingold AA, Resnick HS, Kilpatrick DG: Predictors of fear of crime in older adults. J Anxiety Disord 2004, 18(3):385-396.

20. Halpern D: Social Capital Cambridge: Polity Press; 2005.

21. Graham H: The challenge of health inequalities. In Understanding Health Inequalities Edited by: Graham H. Berkshire: Open University Press; 2000:3-21.

22. Matei S, Ball-Rokeach SJ, Qiu JL: Fear and misperception of Los Angeles urban space - a spatial-statistical study of communication-shaped mental maps. Commun Res 200I, 28(4):429-463.

23. Newman O: Defensible Space. Crime Prevention Through Urban Design New York: Collier Books; 1973.

24. Greenberg SW, William RM: Neighborhood design and crime. A test of two perspectives. J Am Planning Assoc 1984, 50(1):48-6I.

25. Wandersman A, Nation M: Urban neighborhoods and menta health - psychological contributions to understanding toxicity, resilience, and interventions. Am Psychol 1998, 53(6):647-656.

26. Wood L, Shannon T, Bulsara M, Pikora T, McCormack G, Giles-Corti $B$ : The anatomy of the safe and social suburb: an exploratory study of the built environment, social capital and residents perceptions of safety. Health Place 2008, I4(I):15-3I.

27. Lindstrom M, Merlo J, Ostergren PO: Social capital and sense of insecurity in the neighbourhood: a population-based multilevel analysis in Malmo, Sweden. Soc Sci Med 2003, 56(5): IIII-III20.

28. Chandola $\mathrm{T}$ : The fear of crime and area differences in health Health Place 200I, 7(2): I05-II6.

29. Stafford M, Chandola T, Marmot M: Association between fear of crime and mental health and physical functioning. Am J Public Health 2007, 97(II):2076-208I.

30. Shaw M: Housing and public health. Annu Rev Public Health 2004 25:397-4I8

31. Macintyre S, Ellaway A, Cummins S: Place effects on health: how can we conceptualise, operationalise and measure them? Soc Sci Med 2002, 55(I): 125-139.

32. McLaren L, Perry R, Carruthers L, Hawe P: Introducing a means of quantifying community reputation: the print media as a data source. Health Place 2005, I I (2): 187-194.

33. Ellaway A, Macintyre S: Does housing tenure predict health in the UK because it exposes people to different levels of housing related hazards in the home or its surroundings? Health Place 1998, 4(2): $14 \mid-150$.

34. SCB: Statistiska centralbyrån: NYKO-nyckelkodsystemet. Geografisk indelning för statistikredovisning för delområden inom en kommun [Statistics Sweden. Key-code System. Geographical Classification for Statistical Account] Stockholm: SCB; 2008.

35. Whitzman C: Community safety indicators: are we measuring what counts? Urban Policy Res 2008, 26(2):197-2II.

36. SCB: Statistiska centralbyrån: Undersökningen om levnadsforhållanden, ULF [Statistics Sweden. Swedish Living Conditions Survey] Stockholm: SCB; 1999.

37. Bonnefoy XR, Annesi-Maesano I, Aznar LM, Braubach M, Croxford B, Davidson M, Ezratty V, Fredouille J, Gonzalez-Gross M, van Kamp I, Maschke C, Mesbah M, Moissonnier B, Monolbaev K, Moore R, Nicol S, Niemann H, Nygren C, Ormandy D, Röbbel N, Rudnai P: Review of evidence on housing and health. Background document. Fourth Ministerial Conference on Environment and Health: 23-25 June 2004, Budapest, Hungary 2004 [http://www.euro.who.int/document/ hoh/ebackdoc0l.pdf]. Geneva: WHO

38. FHI: The Swedish National Institute of Public Health. Statens folkhälsoinstitut. Nationella folkhälsoenkäten [National questionnaire on public health] 2004 [http://www.fhi.se]

39. Ferraro KF, LaGrange R: The measurement of fear of crime. Sociol Inq 1987, 57:70-I0I.

40. Macintyre S, Maciver S, Sooman A: Area, class and health should we be focusing on places or people. J Soc Policy 1993 , 22:2I3-234.

4I. Hair JF, Black B, Babin B, Anderson RE, Tatham RL: Multivariate Dato Analysis Upper Saddler River, NJ: Pearson Prentice Hall; 2006.

42. D'Agostino RB, Balanger A, D'Agostino RB Jr: A suggestion for using powerful and informative tests of normality. Am Statist |990, 44(4):3|6-32|.
43. Goffman E: Stigma. Notes on the Management of Spoiled Identity New Jersey: Penguin Books; 1963.

44. Gregory R, Slovic P, Flynn J: Risk perceptions, stigma, and health policy. Health Place 1996, 2(4):213-220.

45. Wilson JQ, Kelling GL: Broken windows. Atlantic Monthly I982, 249(3):29-38.

46. Perkins DD, Meeks JW, Taylor RB: The physical environment of street blocks and resident perceptions of crime and disorder: implications for theory and measurement. J Environ Psychol 1992, I 2:21-34.

47. Sampson RJ, Raudenbush SW, Earls F: Neighborhoods and violent crime: a multilevel study of collective efficacy. Science 1997 , 277(5328):918-924.

48. Sampson RJ, Raudenbush SW: Systematic social observation of public spaces: a new look at disorder in urban neighborhoods. Am J Sociol 1999, I05(3):603-65 I.

49. Kruger DJ, Reischl TM, Gee GC: Neighborhood social conditions mediate the association between physical deterioration and mental health. Am J Community Psychol 2007, 40(3-4):26I-27I.

50. Steptoe A, Feldman PJ: Neighborhood problems as sources of chronic stress: development of a measure of neighborhood problems, and associations with socioeconomic status and health. Ann Behav Med 200I, 23(3): I77- 185.

5I. Sampson RJ: Neighborhood-level context and health: lessons from sociology. In Neighborhood and Health Edited by: Kawachi I, Berkman LF. New York: Oxford University Press; 2003:I32-I 46.

52. Morenoff JD, Sampson RJ, Raudenbush SW: Neighborhood inequality, collective efficacy, and the spatial dynamics of urban violence. Criminology 200I, 39(3):517-559.

53. Guest AM, Cover JK, Matsueda RL, Kubrin CE: Neighborhood context and neighboring ties. City Community 2006, 5(4):363-385.

54. Kruger DJ, Hutchison P, Monroe MG, Reischl T, Morrel-Samuels S: Assault injury rates, social capital, and fear of neighborhood crime. J Community Psychol 2007, 35(4):483-498.

55. Koskela H, Pain R: Revisiting fear and place: women's fear of attack and the built environment. Geoforum 2000, 3I(2):269-280.

56. LaGrange RL, Ferraro KF, Supancic M: Perceived risk and fear of crime - role of social and physical incivilities. J Res Crime Deling 1992, 29(3):3।I-334.

57. Ellen IG, Turner MA: Does neighborhood matter? Assessing recent evidence. Hous Policy Debate 1997, 8(4):833-866.

58. Haney T]: "Broken windows" and self-esteem: Subjective understandings of neighborhood poverty and disorder. Soc Sci Res 2007, 36(3):968-994.

59. Cozens PM: Sustainable urban development and crime prevention through environmental design for the British city. Towards an effective urban environmentalism for the 2 I st century. Cities 2002, 19(2): 129-137.

60. Bennett TH, Holloway KR, Farrington DP: Effectiveness of Neighbourhood Watch in Reducing Crime. Report Prepared for BRA Stockholm: Swedish National Council for Crime Prevention; 2008:9.

61. Massey DS: The age of extremes: Concentrated affluence and poverty in the twenty-first century. Demography 1996, 33(4):395-4I2.

62. Guite HF, Clark C, Ackrill G: The impact of the physical and urban environment on mental well-being. Public Health 2006, I 20( I 2): I I I7-I I 26.

63. Ellaway A, McKay L, Macintyre S, Kearns A, Hiscock R: Are social comparisons of homes and cars related to psychosocial health? Int J Epidemiol 2004, 33(5): 1065-I07I.

64. Ziersch AM: Health implications of access to social capital: findings from an Australian study. Soc Sci Med 2005, $61(10): 2119-2131$.

\section{Pre-publication history}

The pre-publication history for this paper can be accessed here:

http://www.biomedcentral.com/1471-2458/9/221/pre pub 